\title{
Tectonic evolution and its control over deposition in fault basins: A case study of the Western Sag of the Cenozoic Liaohe Depression, eastern China
}

\author{
Zhang Zhen ${ }^{1,2 *}$, Bao Zhidong, ${ }^{3,}$, Tong Hengmao ${ }^{3,4}$, Wang Yong ${ }^{5}$ and Li \\ Haowu $^{6}$ \\ ${ }^{1}$ Institute of Mineral Resources, Chinese Academy of Geological Sciences, Beijing 100037, China \\ ${ }^{2}$ Key Laboratory of Saline Lake Resources and Environments, Ministry of Land and Resources, Beijing 100037, China \\ ${ }^{3}$ College of Geosciences, China University of Petroleum, Beijing 102249, China \\ ${ }^{4}$ State Key Laboratory of Petroleum Resource and Prospecting, China University of Petroleum, Beijing 102249, China \\ ${ }^{5}$ PetroChina Dagang Oilfield Company, Tianjin 300280, China \\ ${ }^{6}$ Research Institute of Petroleum Exploration \& Development, PetroChina, Beijing 100083, China
}

(C) China University of Petroleum (Beijing) and Springer-Verlag Berlin Heidelberg 2013

\begin{abstract}
The main petroliferous basins in eastern China are Cenozoic fault basins, most of which have experienced two-stage tectonic evolution, i.e., rifting subsidence in the Paleogene and post-rifting thermal subsidence in the Neogene-Quaternary. The episodic tectonic evolution and syndepositional faulting had significant influence on the fault basins in terms of accommodation space, deposition rate, and depositional facies zones. In this study, the tectonic deformation characteristics and the tectonic-depositional evolution of the Western Sag of the Cenozoic Liaohe Depression were investigated by comprehensive analysis of the available geological and geophysical data using the modern theory of tectonic geology and the balanced section technique. The tectonic deformation of the Cenozoic fault basin was characterized by superimposed faults and depression. In addition, there existed relatively independent but still related extensional tectonic systems and strike-slip tectonic systems. The tectonic evolution of the fault basin involved five stages, i.e., initial rifting stage $\left(\mathrm{E}_{2} \mathrm{~s}^{4}\right)$, intense faulting stage $\left(\mathrm{E}_{2} \mathrm{~s}^{3}\right)$, fault-depression transition stage $\left(\mathrm{E}_{3} \mathrm{~s}^{1-2}\right)$, differential uplifting stage $\left(\mathrm{E}_{3} \mathrm{~d}\right)$, and depression stage $(\mathrm{N}-\mathrm{Q})$. According to the characteristics of tectonic development and evolution of the Western Sag, the depositional evolution in the Cenozoic fault basin was divided into two stages, i.e., multi-episodic rifting filling in the Paleogene and post-rifting filling in the Neogene-Quaternary. The former rifting stage was further subdivided into four episodes with different characteristics of depositional development. The episodic faulting controlled the filling process and filling pattern of the Cenozoic Western Sag as well as the development and spatial distribution of associated depositional systems, whereas the syndepositional faults that developed in multiple stages in various tectonic positions controlled the development of depositional systems and sand bodies in the Western Sag. That is, the fault terraces on steep slopes controlled the development of sand bodies, the fault terraces on gentle slopes controlled the development of low-stand fan bodies, and the fault terraces or fault troughs in the central basin controlled the development of fluxoturbidite bodies.
\end{abstract}

Key words: Fault basin, syndepositional fault, tectonic evolution, depositional evolution, Western Sag

\section{Introduction}

Continental fault basins are an important type of petroliferous basin worldwide. Due to their unique geological features and abundant hydrocarbon resources, continental fault basins are of increasing importance in hydrocarbon geology. On the eastern continent and coast in China, there

*Corresponding author. email: zhangzhenbj@aliyun.com

Received June 22, 2012 are $\sim 230$ Meso-Cenozoic continental fault basins with distinct characteristics, e.g., the Songliao Basin, the Bohai Bay Basin, the Northern Jiangsu Basin, the Nanxiang Basin, the Jianghan Basin, and the Pearl River Mouth Basin (Liu et al, 2008). In recent years, in-depth studies have been conducted on the fault basins in China regarding tectonic style, sequence models, depositional filling, and the exploration methods for subtle reservoirs (Zhang et al, 2004; Yin et al, 2006; Zhong et al, 2006; Song, 2007; Tong et al, 2008; Zhu et al, 2008; Fu, 2009; Liu and Zhang, 2011; Xu et al, 2011; Tang and Cui, 
2012; Tong, 2012). Substantial achievements have been made in exploration for lithological and stratigraphic reservoirs in continental fault basins (Feng, 2005), especially in the steep slope zones in the Dongying, Zhanhua, Chezhen, Nanpu, Raoyang, and Damintun sags.

Tectonism plays an important role in controlling the filling process of fault basins. Episodic tectonic evolution (or episodic tectonic activity), changes in tectonic subsidence rate, and syndepositional tectonic activities impose significant influences on fault basins regarding the accommodation space, the deposition rate, and the depositional facies zones (Li et al, 2000; Lin et al, 2003; Zheng and He, 2004). At present, conjoint analysis of tectonism and deposition has received increasing attention and has become a focus of basin analysis (Gawthorpe and Leeder, 2000; Contreras and Scholz, 2001; McLeod et al, 2002; Barrier et al, 2002; DeVault and Jeremiah, 2002; Hoppie and Garrison, 2002; Young et al, 2003; Jones et al, 2004; Gomez et al, 2005; Yang et al, 2005; Pascucci et al, 2006; Aschoff and Schmitt, 2008; Duerto and McClay, 2009; Carmona et al, 2010; Fillon et al, 2012). Associated research has mainly focused on the progress in foreland basin deposition and obduction and the relationships between basin extension and deposition as well as between strike-slip and depositional processes. The above topics are primarily studied by basin analysis combined with multi-subject analyses, e.g., provenance analysis, facies analysis, sequence and overlay of the accumulation bodies, combination of seismic and logging data with outcrop sections, balanced cross section analysis and basin simulation. These analysis methods emphasize the depositional mode, depositional style, and depositional geometrical kernel of the sediments in basins, with the restriction of tectonic activity and episodes, sea level change, ancient climate, and provenance supply. In addition, the fillings of a fault basin reflect its tectonic evolutionary characteristics. Studies have shown that deposition is tightly linked with tectonic deformation in different tectonic systems. Still, the exact relationship and the synchronous evolution rule of tectonism and deposition in fault basins need to be further investigated from the perspective of the controlling effect of tectonic evolution and syndepositional fault activities on the distribution of sediment dispersion system and depositional facies zones.

Previous work has investigated the tectonic development and depositional filling in a number of sags of the Bohai Bay Basin, including the Dongying, Zhanhua, Chezhen and Huimin sags of the Jiyang Depression, the Nanpu Sag of the Huanghua Depression, the Damintun Sag of the Lower Liaohe Depression, and the Nanyang Sag of the Nanxiang Basin. The characteristics of the fault basins are summarized as follows: 1) the tectonic styles are relatively simple and mainly include graben, half graben, or complex graben. Of these, half graben is the most common style. The control faults and boundary faults are mainly normal faults or syndepositional faults. 2) The multi-episodic tectonic evolution involved an early rifting (faulting) stage related to extension and mantle uplift and a late post-rifting depression stage related to thermal decay and subsidence. 3) The faults were most active at the edge and within the basin. Episodic faulting controlled the depositional evolution as well as regular changes in the sediment filling of the basin. and 4) A slope break belt, which was formed by the long-term activity of syndepositional faults, restricted the changes in the accommodation space for sediment filling and controlled the development of depositional systems as well as the distribution of sand bodies.

In the present study, we took as an example the Western Sag of the Liaohe Depression (WSLD) that has been subjected to a relatively high degree of exploration in an attempt to elucidate the tectonic evolution of fault basins and to discuss the control of episodic faulting activities over the filling process and style as well as the development and spatial distribution of various depositional systems in fault basins.

\section{Geological setting}

The WSLD is a negative Tertiary tectonic unit of the Lower Liaohe Depression in the northeastern Bohai Bay Basin. The Western Sag is connected by the Central Salient to the Eastern Sag of the Liaohe Depression to the east, and is bounded by the Yanshan Fold Belt to the west, the Liaodong Bay Sag to the south, and the Northern Sag of the Liaohe Depression to the north. The topography is steep in the east with gentle slopes towards the west and high in the north with low structures towards the south. The sag is dustpanshaped and inclines towards the southeast. The long axis extends towards the northeast, $\sim 115 \mathrm{~km}$ in length and 22 $\mathrm{km}$ in width, with a continental exploration area of $\sim 2,560$ $\mathrm{km}^{2}$. The Western Sag serves as the main hydrocarbonbearing region in the Liaohe Depression and a total of 10 sets of hydrocarbon-bearing strata have been found, e.g., the Archaeozoic strata, the Proterozoic strata, the Palaeozoic strata, the Palaeogene Shahejie and Dongying formations, and the Neogene Guantao and Minghuazhen formations. Of these, the Palaeogene Shahejie Formation is the main hydrocarbonbearing strata (Tong et al, 2008). From its tectonic and depositional characteristics, the Western Sag can be classified into nine secondary tectonic units (Fig. 1), i.e., the western slope, Qingshui subsag, Panshan-Chenjia subsag, NiuxintuoTai'an subsag, Shuangtaizi tectonic zone, Xinglongtai buried hill tectonic zone, Lengjia compression and shear tectonic zone, and pitching zone in the south of the Central Salient. There are three tectonic zones in the short axis direction, i.e., western gentle slope zone, central deep sinking zone, and eastern steep slope zone.

The tectonic deformation of the Cenozoic Western Sag is generally characterized by superimposition of the extensional tectonic systems mainly consisting of NNE-NE-trending basement normal faults and the strike-slip tectonic systems induced by the right lateral strike-slip displacement of NNE-trending deep faults. Of these, the $\mathrm{E}_{2} \mathrm{~s}^{3}-\mathrm{E}_{2} \mathrm{~s}^{4}$ primarily controlled the formation and evolution of the Paleogene fault basin (Fig. 1). A variety of tectonic styles coexisted in the tectonic layers of the Cenozoic Western Sag, e.g., extensional, strike-slip, and inversion structures. The distribution of different tectonic styles followed certain patterns, i.e., EWtrending normal faults, NS-trending reverse faults, NEtrending strike-slip faults, NNE-trending compression and 


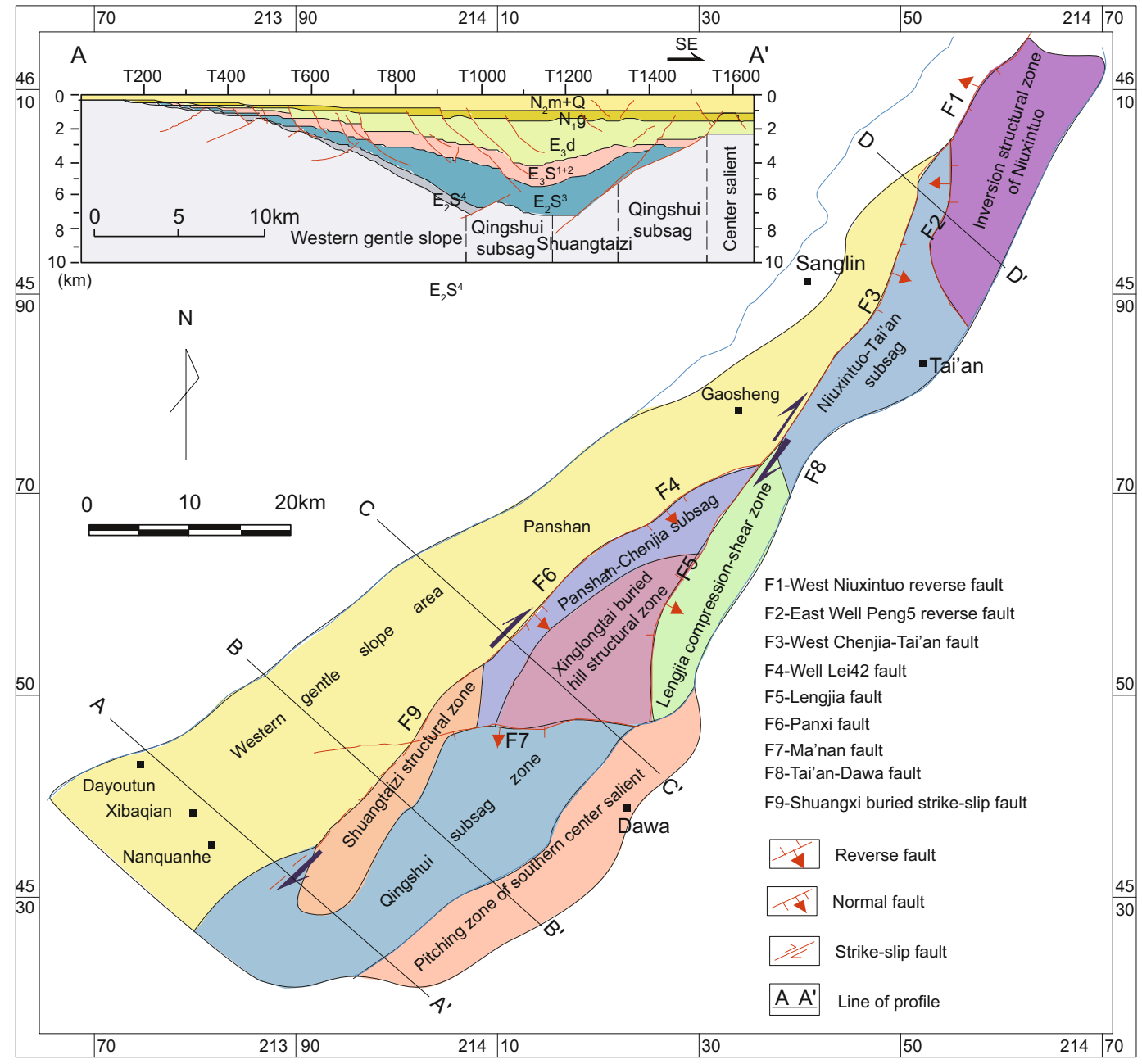

Fig. 1 Tectonic units and division of the fault systems of the WSLD

shear faults, and ENE-trending tension and shear faults. The main fault systems mostly occurred at the edge of the sag, characterized by large scale and long-term development. The main faults in the steep slope controlled the occurrence, growth and the degree of development of the sag, whereas those in the central sag with multi-stage development controlled the occurrence and development of multiple depocenters in the sag (Fig. 2).

During the Paleogene period, the tectonic activities were dominated by block faulting, mainly including tensional normal faulting and tilting displacement of deposition layers. Due to the continuous movements of tensional faults, the deposition rate of the downthrown side of normal faults was commonly greater than that of the uplifted side. Under the joint action of tectonism and deposition, syndepositional faults of different scales were developed in the Paleogene Western Sag and these played a further leading role in the generation and evolution of the sag as well as the control of the distribution of relevant depositional systems and sand bodies.

\section{The type of syndepositional faults}

Previous research has indicated that the significant geomorphic changes in a deposition period are mainly related to the activity of large-scale syndepositional faults or syndepositional fault belts (Allen et al, 1997; Bernal and Hardy, 2002; Zhuravlev and Shipilov, 2008). Under the tension effect, a series of syndepositional faults or syndepositional fault belts can be formed in fault basins by different faulting actions, e.g., domino block faulting, listric faulting, antithetic adjustment faulting, and strike-slip tensional action. Once formed, the syndepositional faults will have long-term activity throughout the rifting stage due to the concentration tendency of the stress, which causes significant differential settlement and constitutes the boundaries of tectonic palaeogeomorphic units and the depositional systems tracts. The palaeogeomorphic abrupt zone or slope zone formed by the large-scale and long-term activities of syndepositional structures (faults) is referred to as structural (fault) slope-break zone.

In the WSLD, multi-stage fault slope-break zones could be formed by different levels of syndepositional faults in steep slope, gentle slope and subsag zones, leading to the formation of extremely complex tectonic palaeogeomorphology. The syndepositional faults developed in the sag are mainly basin edge faults and adjusting faults within the basin. Overall, these syndepositional faults constitute the boundaries of the palaeotectonic units, e.g., salient, gentle slope, subsag, and steep slope. The syndepositional faults have multiple patterns 


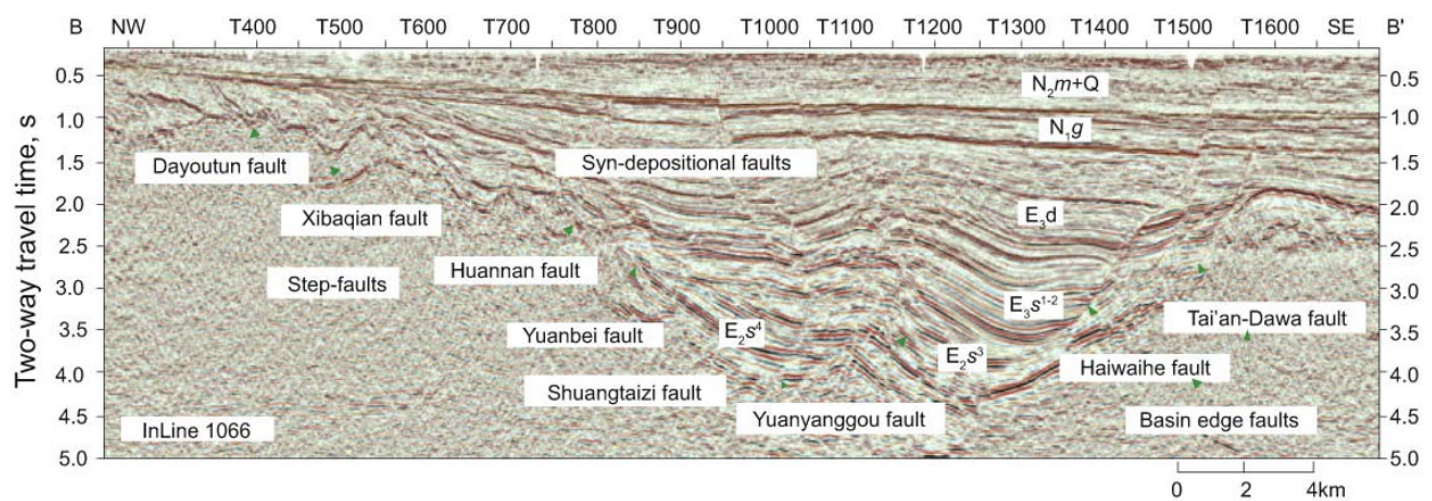

(a)

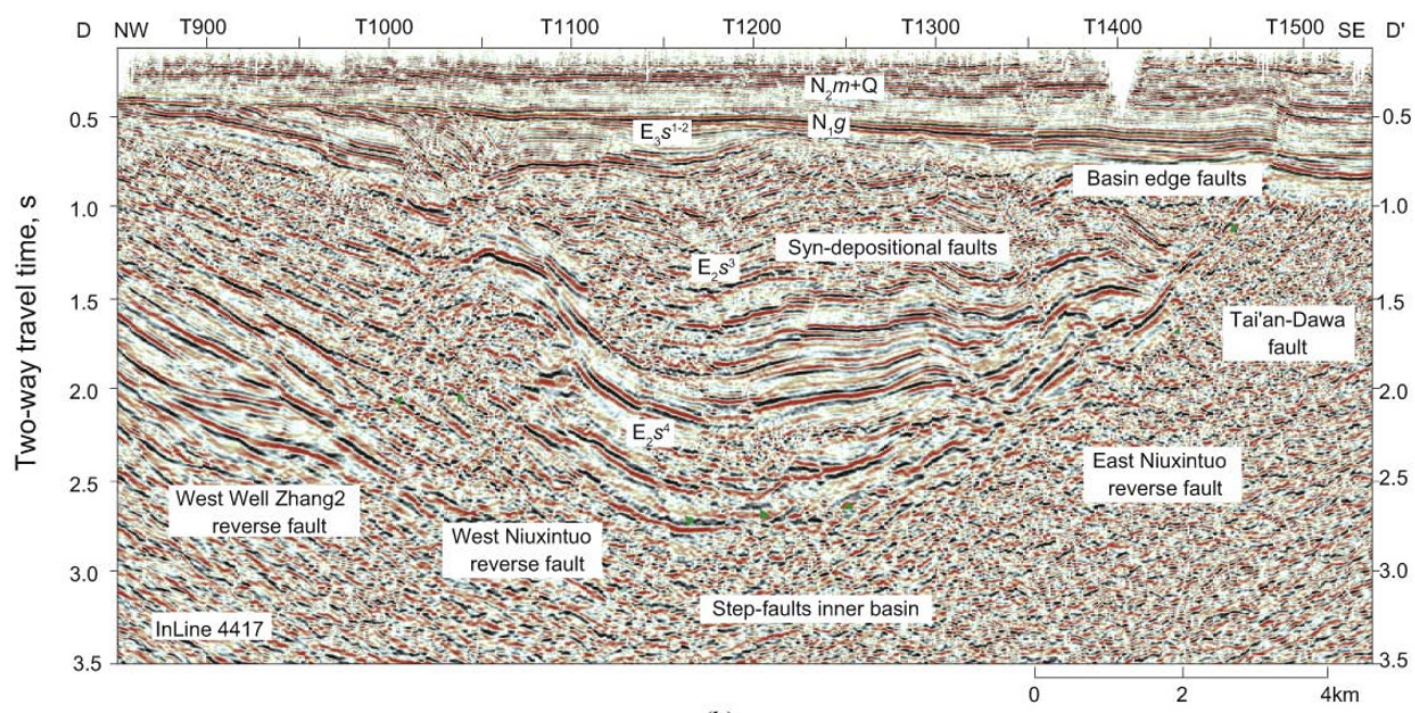

(b)

Fig. 2 Seismic profiles of the WSLD (position referred to Fig. 1)

(a) In Line 1066 (BB'); (b) In Line 4417 (DD')

of plane combination, including paralleling or en echelon fault system, comb-like fault system, broom-like fault system, and fault adjustment zones. In cross section, the syndepositional faults are usually curved and steep in the upper part, and are usually gentle in the lower part with dips ranging from $40^{\circ}$ to $80^{\circ}$. The slopes are gentle towards the deep fracture surface and gradually become parallel to the surface of the mudstone layer, eventually slipping and disappearing in the interlayer or within the mudstone layers (Figs. 2, 3). Basin edge faults developed in the eastern steep slope, i.e., the Tai'an-Dawa and Haiwaihe faults, have the largest slope gradient and fault displacement, followed by the step-fault zone consisting of Huannan, Yuanbei, Dujiatai, and Panxi faults in the west gentle slope. The smallest development scale is observed in the faults in the subsag, including the Shuangtaizi, Yuanyanggou, and Xingxi faults.

According to their combination patterns in the plane and section, the main syndepositional faults are divided into three types, i.e., fault terrace, fault scarp, and steep slope, which respectively correspond to the development of three types of depositional systems, i.e., alluvial fan-fan-deltas-farshore turbidite fan, alluvial fan-nearshore turbidite fan, and alluvial fan - fan-deltas - near-shore turbidite fan.

\section{Cenozoic tectonic evolution}

Previous work has reconstructed the tectonic subsidence history of several typical continental fault basins, e.g., the Bohai Bay Basin, North Jiangsu Basin, and Nanxiang Basin (Tong et al, 2008). Evidence shows that such basins have experienced multi-episode subsidence and thus were controlled by lithospheric extension and episodic faulting. In addition, these fault basins show similarities in the evolution of their tectonic framework. Thus, the Cenozoic continental fault basins in eastern China have mostly undergone two-stage tectonic evolution, i.e., rifting subsidence in the Paleogene and post-rifting thermal subsidence (or depression) in the Neogene-Quaternary. These two stages basically complete an entire cycle of rifting. Because the Cenozoic rifting is characterized by episodic and progressive development, the basins generally have undergone a short-term regional uplift after each extension period of rifting. As a result, the pre-depositional formations were partly denuded, leading to the formation of several parallel or small-angular unconformable surfaces comparable with each other in the regional range. 

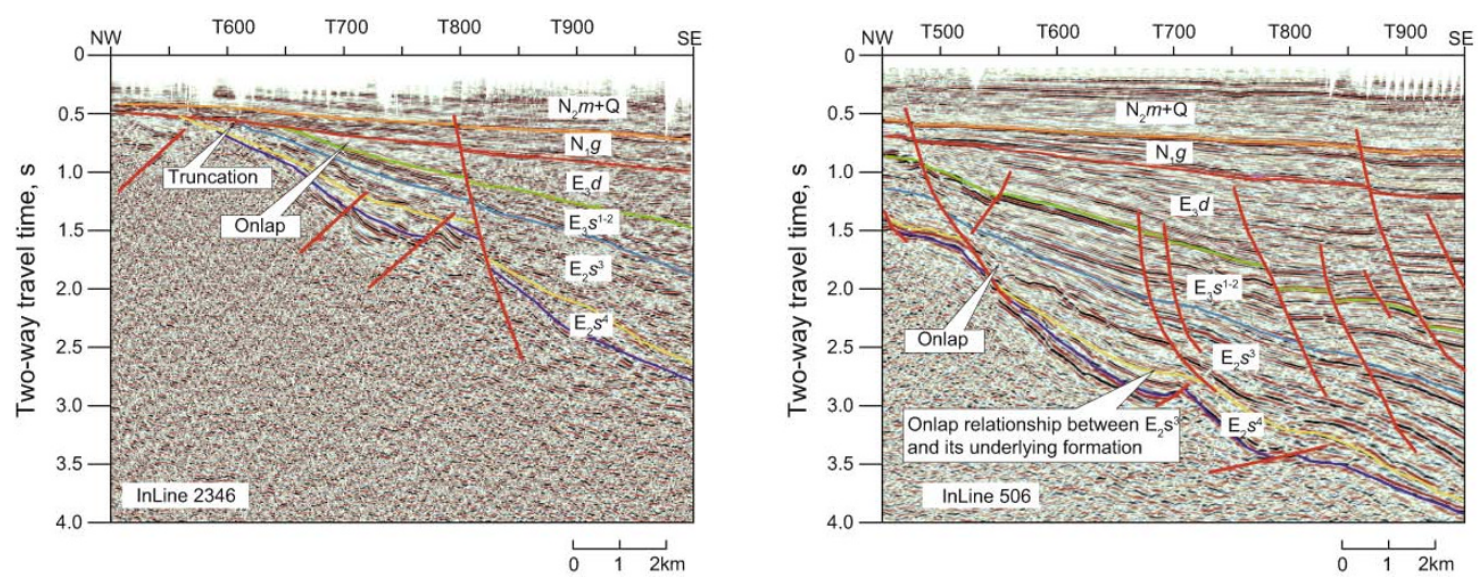

Fig. 3 Seismic reflection characteristics of the top and bottom of stratigraphic sequence boundaries in the WSLD

\subsection{Division of tectonic layers}

A key step in the division of tectonic layers is to identify the unconformable interface in the seismic profile and to track its corresponding parallel unconformity or integration interface. There are mainly five types of seismic reflection termination, i.e., onlap, downlap, toplap, truncation, and concordance.

\section{1) Truncation}

Due to erosion, the unconformity occurs at the top of a seismic sequence, with the reflective layer overlying the sequence boundary intersected at a specific angle with the reflective layer underlying the sequence boundary. The seismic reflection parameters of the formation, e.g., amplitude, continuity, and frequency, show large variations above and below the sequence boundary. The layer velocity under the boundary is generally higher. According to the geological significance analysis, the truncation surface is a long-term depositional hiatus surface. In the WSLD, the sequence boundary between the Guantao Formation and its underlying Dongying Formation shows a typical truncation relationship.

\section{2) Toplap}

The underlying strata of the Sha-1 Member gradually intersect at a small angle with the overlying strata of the Dongying Formation, and the reflective layer gradually disappeared toward the up dip direction. After the deposition of the Sha-1 Member, the top depositional base was too low for aggradation during the deposition of the Dongying Formation, leading to runoff scouring erosion of the sediments and simultaneous forward movement of the deposition. Under this circumstance, the top boundary of the sequence acted as an unconformable interface as well.

\section{3) Onlap}

In the seismic profile, the overlapping of a reflective layer terminates towards the up dip direction of the base level of deposition. Geologically, a new formation overlaps and pinches out towards the up dip direction of the outcrop of the underlying older strata. The onlap is caused by deposition in gradually expanded waters and commonly occurs in steep or gentle slopes in lake basins.

Based on systematic research of the reflection characteristics of stratigraphic sequence boundaries, five unconformity interfaces are recognized in the Cenozoic strata of the WSLD, i.e., the bottom boundary unconformity of the Sha-4 Member (Cenozoic bottom boundary unconformity), the bottom boundary unconformity of the Sha-3 Member, the bottom boundary unconformities of the Sha-1 and Sha2 Members, the bottom boundary unconformity of the Dongying Formation, and the bottom boundary unconformity of the Neogene strata. Correspondingly, the Cenozoic basin in the WSLD can be divided into five tectonic layers (Fig. 3).

\subsection{Tectonic evolution}

In the balanced geological cross section, deformation structures are completely restored to a reasonable geological section in an undeformed state following geometric principles. To establish a reasonable geological crosssection, two principles have been summarized: 1) In a geometrically reasonable cross-section, the strata have consistent length in the case of no discontinuity; and 2) In a specific geological environment, there can only exist one specific set of structures. In the balanced section, the section line needs to be in parallel with the direction of the tectonic movement, that is, vertical to the direction of the tectonic belt. The basic constraint condition is that the volume of the material remains constant before and after the deformation, the so-called Constant Volume Principle (or Constant Area Principle in the section of the vertical structure). In a word, if a structural section can be restored to an undeformed state, then it is a reasonable geological cross section. So far, the above principles have mainly been applied to the structure of compressional tectonic deformation in quantitative studies and associated restoration practices.

Despite the incomplete section area, the cross section of the strike-slip tectonic zone can be compensated according to the geological model and then reconstructed following the geometric principles. Due to the fault effect caused by the strike-slip faults, the stratigraphic thickness is inconsistent on the two sides of the faults. Since the slides on both sides of the cross section are opposite to each other, we assume that only one part is sliding while the other part remains still. According to the stratigraphic thickness of stable part, the thickness of the sliding part is subjected to appropriate compensation or erosion, allowing the thickness matching of the two strata, thus maintaining their geological rationality. 
In an extensional tectonic zone, especially an extensional basin, the strata and tectonic movement are often synchronously developed. That is, the occurrence and development of tectonic movement are associated with the burial of old strata and gradual deposition of the new strata. As influenced by regional multi-stage tectonic movements, the basin evolution has multi-stage characteristics, thus commonly leading to the superimposition of tectonic deformations. Currently, it remains difficult to analyze extensional basins reasonably and quantitatively, and relevant research is just in the beginning stage.

In the present study, the regional profile ( $\mathrm{CC}^{\prime}$ ) of the WSLD was reconstructed followed the basic idea of basin structural analysis. This cross section was extracted from the latest contiguous three-dimensional seismic data. Firstly, the seismic section was subjected to fine structural interpretation. Combined with other data such as well depth, variable velocity time-depth conversion was achieved and a geological section was accurately established. Then, the section was restored layer by layer to the state prior to deposition through a few steps, e.g., decompaction correction, erosion compensation, fault distance elimination, and layer flattening. Finally, the structural states of all stages were combined to obtain the detailed structural evolution history.

In the WSLD, the five Cenozoic tectonic layers, i.e., Sha-4 Member, Sha-3 Member, Sha-1 Member and Sha-2 Member, Dongying Formation, and Guantao Formation-Quaternary, respectively represent the five periods of the formation and evolution of the Cenozoic basin, i.e., initial rifting stage $\left(\mathrm{E}_{2} \mathrm{~s}^{4}\right)$, intense faulting stage $\left(\mathrm{E}_{2} \mathrm{~s}^{3}\right)$, fault-depression transition stage $\left(\mathrm{E}_{3} \mathrm{~s}^{1-2}\right)$, differential uplifting stage $\left(\mathrm{E}_{3} \mathrm{~d}\right)$, and depression stage (N-Q).

\subsubsection{Multi-episodic rifting in the Paleogene (Middle Eocene to Oligocene)}

1) Initial rifting stage. In the Middle Eocene, the WSLD was experiencing a period of active NW-SE-trending extensional fault depression. A few normal high-angle basement faults, e.g., the Tai'an-Dawa, Shuangtaizi, and Xingxi faults (Figs. 2, 4), developed mainly in NW or SW direction, which controlled the stratigraphic distribution and the scale of half grabens in the Sha-4 Member in the sag.

2) Intense faulting stage. The Late Eocene is the main rifting and expanding period of the WSLD. During this period, the range of stratigraphic distribution was significantly expanded. The Tai'an-Dawa fault had intense activities and gradually became the major control fault of the boundaries in the sag. The embryonic form of the "half graben fault" was generated during the deposition of the whole sag. The embryonic form was southeast-faulted and northwestoverlapped, in which the sedimentary cover was thick in the south and thin in the north.

3) Fault-sag transition stage. This stage is characterized by further strengthening and joint development of the preexisting structure. In the Early Oligocene, the Tai'an-Dawa fault that controlled the development of the half graben was associated with inherited movements. The segmentary characteristics of the basement fault were significantly weakened while the characteristics of the unified fault system began to appear (Fig. 4(d)).
4) Differential uplifting stage. In the Middle to Late Oligocene, with the progressive extensional movement of major basement faults, considerable normal faults with opposite/similar tendency to the boundary major faults developed in the sedimentary cover and involved in the extensional deformation of the basin (Fig. 4(c)). In the half grabens of the tectonic slope, the differential uplifting movement caused by the reverse cover faults, together with the tilting movement of the cover block faults, partly restrained the unbalanced subsidence of the depositional surface caused by the tilting movement of the block faults, further forcing the subsidence center to deviate from the major faults and transfer to the geometric center of the sag.

\subsubsection{Depression stage in the Neogene-Quaternary}

Large-scale structural movement tended to cease from the depositional stage of the Neogene Guantao Formation and the extensional volume was substantially smaller during the entire late depositional stage. Then the whole sag area subsided, indicating the beginning of the depression stage. During this period, the movement of major control faults stopped as well, except for the minimal movements caused by secondary faults under the actions of differential gravitational compaction and the generation of a few small-scale new faults (Fig. 4(a), (b)).

\section{Depositional evolution}

The depositional evolution of fault basins in the context of extension was controlled by episodic faulting, and the sedimentation into the basins was regularly changed by the episodic faulting. This mainly acted through alternation of structurally active and stationary phases, which respectively cause expansion and shrinkage of inner continental lacustrine basins.

According to tectonic development and evolutionary characteristics, the depositional evolution of the Paleogene Western Sag of the Liaohe Depression can be divided into four stages with different depositional development characteristics.

1) Initial stage of lacustrine basin filling $\left(\mathrm{E}_{2} \mathrm{~s}^{4}\right)$-Episode I of rifting. In the early stage, the lake basin began to form in the Niuxintuo area in the northern part of the Western Sag. Due to the dry climate and shallow waters, mainly fandelta and lacustrine sediments were developed with some carbonate sedimentation. In the middle and late stages, faulting movement in the Eastern Sag strengthened while the formation in the Western Sag was gradually uplifted. The lake basin subsided steadily with both water depth and semideep lake area increasing. As a result, the subsidence center gradually moved southwards, with fan-delta - shore shallow lacustrine and carbonate sediments widely developed. A fan-delta system was developed in the west, with fandelta sandbodies of the Shuguang and Qijia-Huanxiling sequentially developed from north to south.

2) Expansion stage of lacustrine basin $\left(\mathrm{E}_{2} \mathrm{~s}^{3}\right)$-Episode II of rifting. In this stage, a typical graben-like sag was formed by the long-term intense activity of boundary faults on the east and west sides of the Western Sag of the Liaohe Depression. The climate changed from semiarid to humid. 

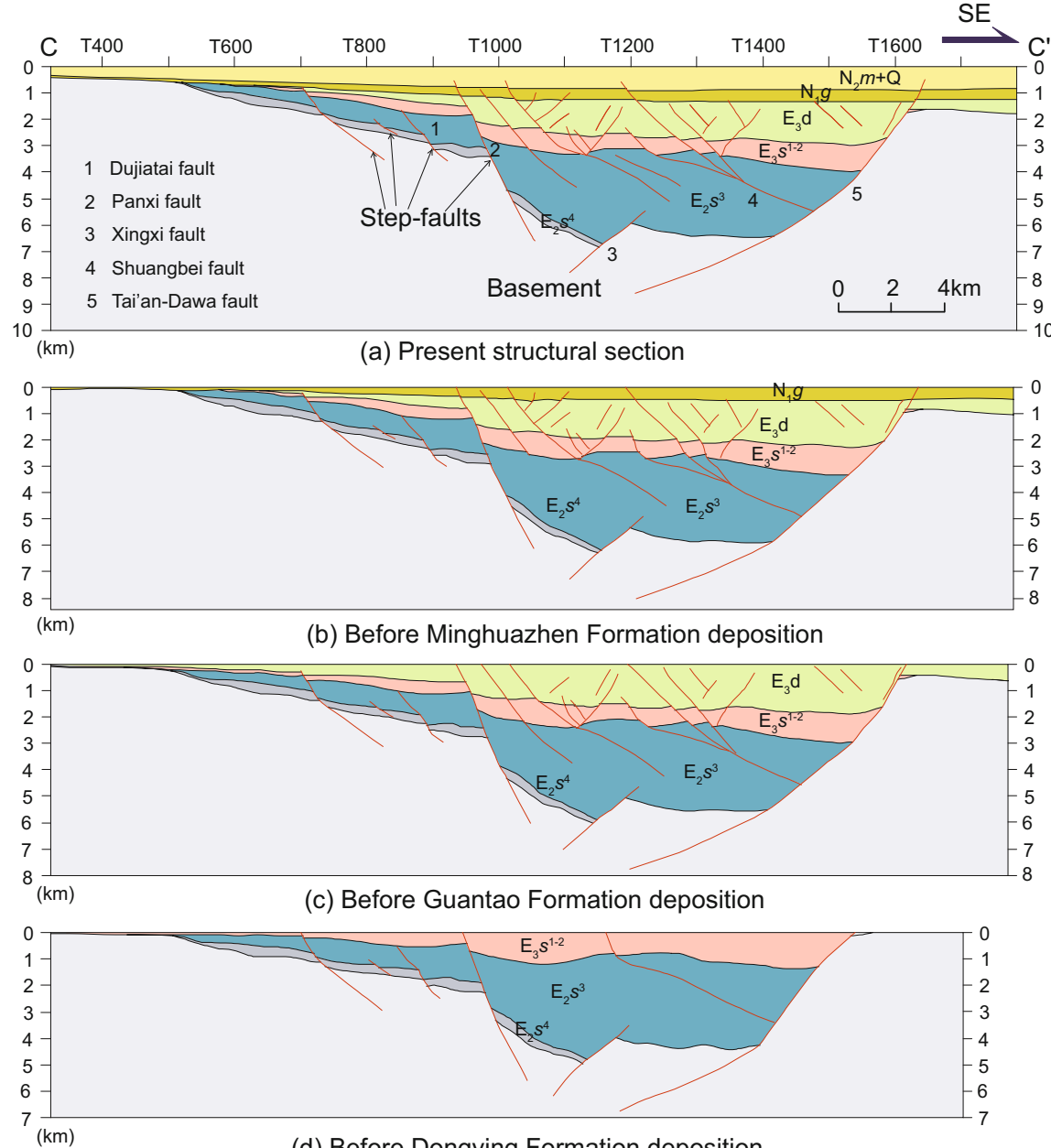

(d) Before Dongying Formation deposition

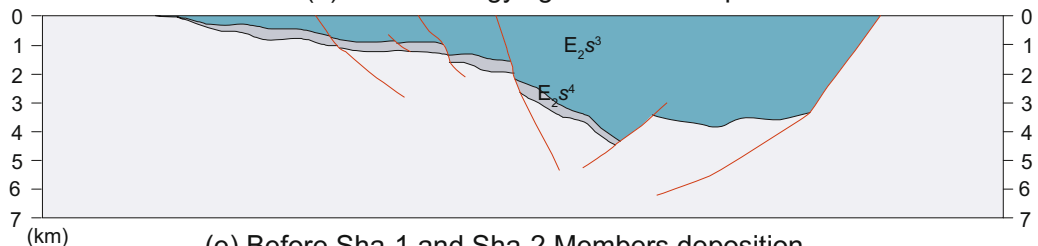

(e) Before Sha-1 and Sha-2 Members deposition
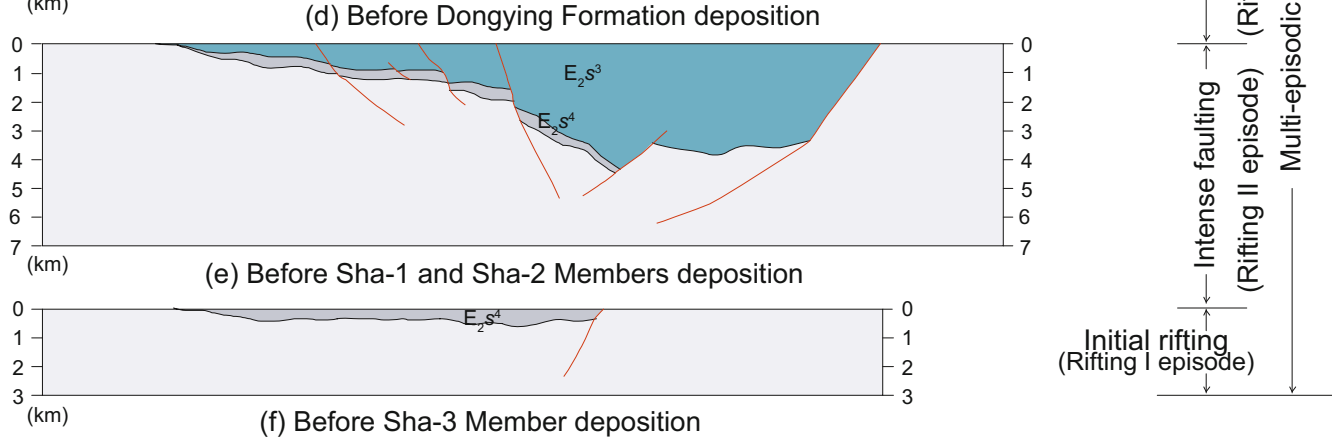

Fig. 4 Structural history of the section CC' in the WSLD (In Line 1946, position referred to Fig. 1)

The lake depth rapidly increased, leading to the formation of a vast-area deep-water faulted lacustrine basin. Fan-delta and lacustrine sediments still dominated the north of the sag. Slump turbidite fans were developed in the Leijia and Lengjia areas, with beachy turbidite fans developed in the southern Lengjia area. Since the sediment-supply capability of the provenances of the Western and Central salients gradually increased and the fan bodies of fan-delta gradually moved southwards, the depositional system in the western slope was dominated by fan-delta - off-shore turbidite fan-lacustrine facies. Alluvial fan - beachy turbidite fan-lacustrine facies was developed in the eastern steep zone and fault trough gravity flow channel facies was developed in northern part of the sag (Figs. 5, 6).

3) Continuous expansion of the lacustrine basin $\left(\mathrm{E}_{2} \mathrm{~S}^{1-2}\right)$
Episode III of rifting. In this stage, the sag maintained the lake basin environment to a certain range, but the water was obviously shallower than that of the deposition period of the Sha-3 Member. The lake basin remained steep in the east with gentle slopes towards the west. It was narrow in the north and became wide towards the south. The main facies included fluvial, fan-delta and lacustrine facies. In the eastern and western slopes, steep-slope type and gentle-slope type fandeltas were widely developed.

4) Shrinkage stage of the lacustrine basin $\left(E_{3} d\right)-$ Episode IV of rifting. In the early and middle stages, the northwestern part of the Western Sag was subjected to continuous uplifting. The southeastern areas of the sag descended and the subsidence center and depocenter(s) moved towards southeast. Till the late stage, the entire 


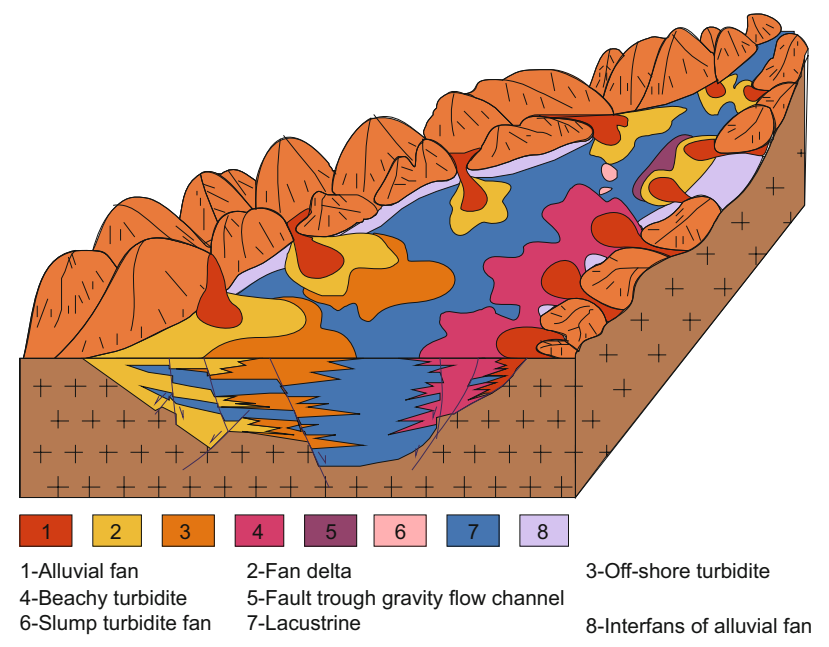

Fig. 5 Sketch of depositional filling during the episode II of rifting in the WSLD

Western Sag experienced intense strike-slip movement and compression. Overall inversion appeared at the end and thus the development of the Paleogene lake basin was completed. In the northern part of the sag, the lake basin was associated with sustained water regression, leading to the formation of a set of subaerial alluvial fan and flood plain depositional environments. In the south part of the sag, the environment of the Jintanhai area was dominated by shallow lacustrine facies, with fine grained delta deposition widely developed.
Since the Neogene, the formation thickness has been relatively stable and the lake basin entered the depression stage. The climate was generally dry, and the filling types and patterns were simple, with mainly braided river-alluvial plain facies deposited in the sag.

\section{The control of tectonic evolution over the deposition}

Normal faults exert a major controlling effect on synrift successions in extensional systems through the generation of accommodation space (Schlische, 1991; Gawthorpe et al, 1994; Gawthorpe and Leeder, 2000). Recent advances in understanding the temporal evolution of normal faults have culminated in various analog modeling, seismic reflection, and field studies of fault characteristics, e.g., fault growth, fault length, displacement patterns, displacement rates, and scaling relationships (Morley, 1999; 2002; Morley and Wonganan, 2000; Walsh et al, 2003; Roberts and Michetti, 2004).

In particular, recent field studies have identified normal fault populations that typically comprise segmented arrays of linked, en echelon faults. The latter control the overall displacement distributions and the resulting hanging-wall accommodation patterns (Dawers and Underhill, 2000; McLeod et al, 2002). Modeling results suggest that complex displacement distributions resulted in spatial and temporal variations in the fault-slip activity induced by the stress perturbations associated with fault rupture events and segment

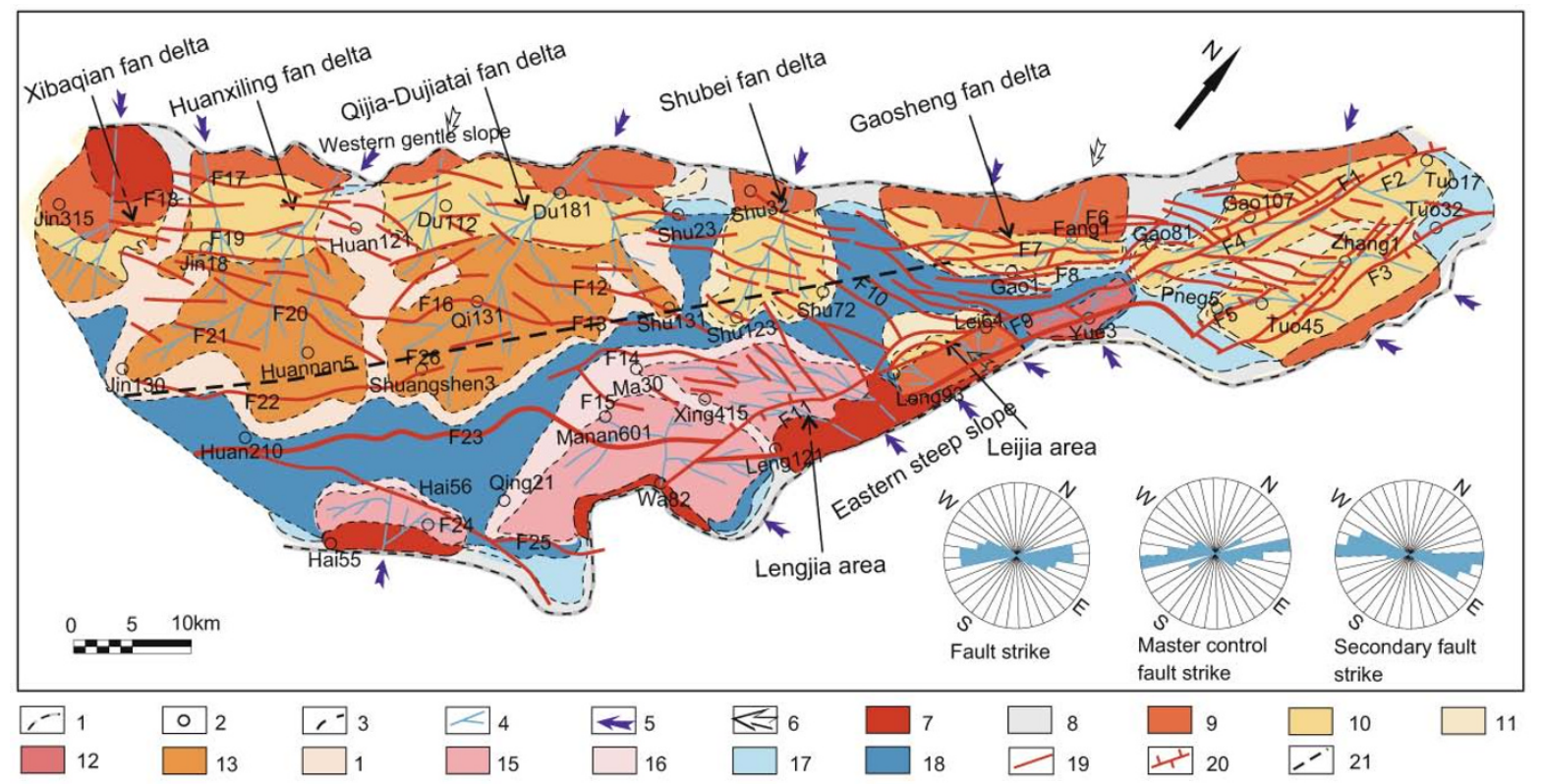

1-Sedimentary boundary; 2-Well; 3-Facies boundary; 4-Channel; 5-Main sources; 6-Minor sources; 7-Alluvial fan; 8-Interfans of alluvial fan;

9-Braided channel of fan delta plain; 10-Underwater distributary channel of fan delta front; 11-Pro-fan delta; 12-Channel of fault trough gravity flow;

13-Braided channel of middle fan of far-shore turbidite fan; 14-Outer fan of turbidite fan; 15-Braided channel of middle fan of nearshore turbidite fan;

16-Outer fan of nearshore turbidite fan; 17-Shore-shallow lacustrine; 18-Semi-deep lake; 19-Normal fault; 20-Reverse fault; 21-Basement buried strike-slip fault

F1-West Well Tuo16 reverse fault F2-West Niuxintuo reverse fault F3-East Niuxintuo reverse fault F4-West Well Zhang2 reverse fault F5-East Well Peng5 reverse fault F26-Shuangxi buried strike-slip fault

$\begin{array}{ll}\text { F6-West Well Fang1 fault } & \text { F11-Lengjia reverse fault } \\ \text { F7-West Well Gao4 fault } & \text { F12-Dujiatai fault } \\ \text { F8-Well Gao1 fault } & \text { F13-Panxi fault } \\ \text { F9-West Chenjia-Tai'an fault } & \text { F14-Xingxi fault } \\ \text { F10-Well Lei40 fault } & \text { F15-Manan fault }\end{array}$

F16-Huannan fault F17-Dayoutun fault F18-Qianxi fault F19-Xibaqian fault F20-Yuanbei fault
F21-Yuanyanggou fault F22-Shuangtaizi fault F23-Tai'an-Dawa fault F24-Branch fault of Dawa la F25-Branch fault of Dawa Ib

Fig. 6 Relationship between major control faults and depositional facies of the Paleogene Sha-3 Member in the WSLD 
interaction in an evolving array (Cowie et al, 2000).

The WSLD mainly underwent tectonic extension and strike-slip processes which primarily controlled the formation of the sag and the distribution of the subsidence center, depocenter(s), and sedimentary facies tract. Additionally, the filling action of the sag recorded each stage of the tectonism process.

\subsection{The control of tectonic evolution over the subsidence center and depocenter(s)}

Changes in formation thickness are indicative of the degree of lacustrine subsidence and the basic outline of the palaeotopography. The formation thickness is controlled by the strength of rifting. At the stage of Sha- 4 deposition, the rifting strength of the WSLD generally decreased from north to south. Correspondingly, the original formation was thicker in the north and thinner in the south, with the subsidence center located in the Niuxintuo area. According to the thickness distribution of dark mudstone, 3-4 depocenters were formed in near-NE direction, which were the result of the initial rifting. That is, the faults controlled the deposition in the sag. In contrast to the Sha-4 deposition, the NW-SEtrending extension system of Sha-3 deposition had great changes, leading to the rifting strength being higher in the south and lower in the north. Moreover, the original formation was thick in the south and thin in the north, showing a wedge-like shape on the whole. Changes in the subsidence and deposition of Sha-1 and Sha-2 are similar to those of Dongying period, but are different from Sha-3 period, and are greater in the southeast but smaller in the northwest. The subsidence center and depocenters gradually moved southwards while the subsidence scope gradually decreased towards the west and the north, eventually transiting to the uplifting areas. However, the depocenters and subsidence center in the Qingshui subsag area changed fundamentally due to the regional stress field changing from extension to tension-shear or compression-shear. These changes resulted in the extension rifting system transitioning into the NEtrending right-lateral strike-slip deformation system. From the Neogene, the formation was wedge-shaped on the whole, being thick in the southeast and thin in the northwest. The distribution of formation thickness reflected the deformation characteristics, mainly thermal subsidence of the depression, as well as the systematic changes in the tectonic stress field from north to south in the Neogene Guantao Formation.

\subsection{The control of tectonic evolution over depositional facies tract}

The stage of tectonic evolution and the episodic changes in subsidence rate commonly control the development of depositional system tracts and the distribution of depositional facies in fault basins, whereas the combination patterns of syndepositional faults in different evolutionary stages determine the composition of specific depositional tract and the distribution of reservoir sandbodies (Liesa et al, 2006).

\subsubsection{Rifting stage}

The long-term movements of syndepositional faults supply potential accommodation space for the deposition of sediments and further control the deposition type of sediments. Taking as an example the depositional period of the Paleogene Sha-3 Member, we discussed the control of fault activities over the distribution of specific depositional facies tract in the WSLD.

In the north part of the Western Sag, the western Well Zhang 2 reverse fault and the western and eastern Niuxintuo reverse faults moved intensely and controlled the deposition of fan-delta fronts in the west and east of the sag (Figs. 2(b), $5)$, whose sediments came from the footwall of the faults. Due to the control by the boundary fault of Tai'an-Dawa, the south Niuxintuo area began to subside, the subsidence centers and depocenters gradually moved southwards, and large-scale fan-delta-shallow lacustrine facies depositional systems developed. On the gentle slope of Gaosheng area, stepped fault belts tended to the east direction and consisted of the western Well Fang 1 fault, western Well Gao 4 fault, and Gao 1 fault. These stepped fault belts, distributed in a $\mathrm{NE}$ direction, the same as the strike of major control faults, controlled the deposition of fan-deltas. The submerged distributary channels of fan-delta fronts were distributed in the upper wall of western Well Gao 4 fault, which mainly consisted of sandstone and provided the reservoir rock bodies of the Lianhua oil deposit in the Gaosheng area.

Along the gentle slope zone, the side of the thrown wall of the rotational fault was a relatively low-lying deep water area which constituted the depocenter of the fan-deltas. In the south part of the west gentle slope, the fault belts that tended in an easterly direction, e.g., the Dujiatai, Dayoutun, Xibaqian, and Huannan faults, controlled the deposition of fan-delta fronts in the Dujiatai, Xibaqian and Huanxiling areas. The Shuangtaizi and Panxi faults adjacent to the subsag fringe probably maintained a large accommodation space and a tectonic low landform, leading to substantial increases in the depositional thickness and further controlling the distribution of off-shore turbidite fans (Figs. 2(a), 4, 6).

On the eastern steep slope, the major control fault, i.e., the Tai'an-Dawa fault was a basin edge fault that controlled the depositional boundaries of alluvial fan and fan-delta facies. At its outside, there was a salient directly supplying the sediment. The coarse clastic sediments were deposited in vertical accretion along the side of the thrown wall, extending along the tectonic strike. The Lengjia reverse fault and the western Chenjia-Tai'an fault controlled the depositional distribution of alluvial fan and beachy turbidite fan facies, while the Well Lei 42 fault controlled the thickened belts of arenaceous sediments of fan-delta fronts. Under the control of both the Tai'an-Dawa major control fault and western fault of Chenjia-Tai'an, gravity flow trough fault channels developed in the north part of the eastern steep slope, and the turbidite sandbodies were distributed between two subparallel faults (Figs. 5, 6).

In the subsag, a number of subsidiary trough faults or stepped-faults developed, and the subsidiary trough faults commonly controlled the distribution of gravity flow or turbidite deposits in the middle of the lake basin, especially the accumulative deposit of dispersed system of sandstones (Figs. 2, 4). 


\subsubsection{Depression stage}

In the Neogene, the WSLD entered its depression stage. The movements of syndepositional faults were weak and played a minor role in controlling the deposition. Based on the peneplane depositional background, mainly fluvial-flood plain deposits developed in the sag.

\subsection{The control of the palaeogeomorphology over the depositional systems and sand bodies}

The palaeogeomorphology units include palaeo-valley, palaeo-slope break belt, palaeo-fault, and palaeo-depression (Bao et al, 2009). According to the characteristics of continental fault basins, the type, structure, and combination style of the units of palaeogeomorphology constantly change during different stages and are closely related to the tectonic evolution, showing a certain degree of diversity and complexity.

\subsubsection{Palaeo-valley and palaeo-river channel}

The development of palaeo-valley systems is closely related to the characteristics of basement faults. Along the extension direction of the faults, the migration of the valley is controlled by the sedimentation. In the WSLD, four basin edge valleys developed from south to north in the south part of the west gentle slope since the lower $\mathrm{E}_{2} \mathrm{~s}^{3}$ Member, which respectively resulted in the Xibaqian, Huanxiling, Qijia-Dujiatai and Shubei fan deltas. When the base level declined and the accommodation space decreased, the valleys were eroded and incised by water and mainly evolved into a channel for sediment transportation. Coarse sediments transported along the channel were deposited on the lower part of the slope, leading to the formation of fan deltas. When the base level rose and the accommodation space increased, the erosion valley would be subjected to depositional filling. The early sediments were sandy and gravelly, which gradually changed upward to fine sediments and tended to form subaqueous channel depositional systems (Fig. 7).

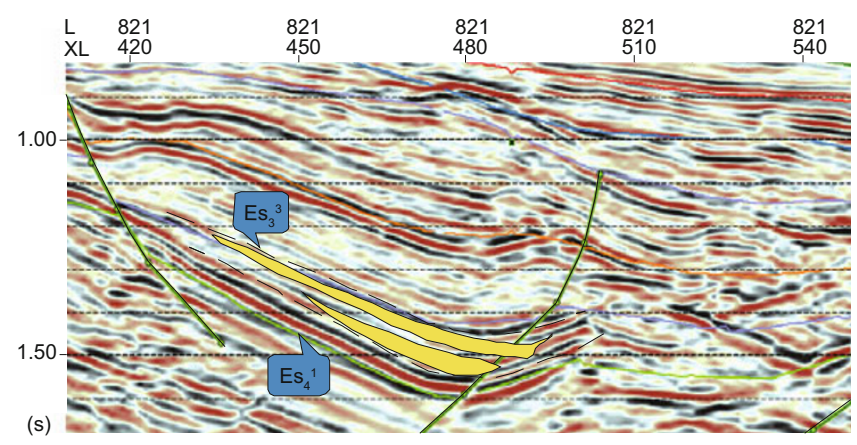

Fig. 7 The control of an incised valley over sand bodies in the Paleogene WSLD (after Bao et al, 2009)

\subsubsection{Fault terrace type of slope break belt and fan delta}

In the fault basins in eastern China, syndepositional fault terraces commonly developed along steep or gentle slopes, which constituted the depositional slope break and controlled the distribution of a few facies (Figs. 2, 5, 6). In general, the fault slope break at the sag edge in the basin constituted the depositional boundaries of alluvial fans or shallow water fan deltas at an early stage of basin evolution. Then, the onlap of the fault terrace basin edge occurred with the formation of edge fracture slope break which further controlled the depositional boundaries of the fan deltas. However, the thickening zone for sand deposition of fan delta front was controlled by the sag edge slope break.

Faulted step slope breaks mainly developed in the western slope of the WSLD. The stepped distribution of the faults constrained the delta and fan delta facies and controlled the formation of nearshore turbidite fans on the downthrown side of the secondary faults along the slope. The scale, particle size and extension distance of the nearshore turbidite fans were related to the source recharge intensity and slope gradient (Fig. $8)$.

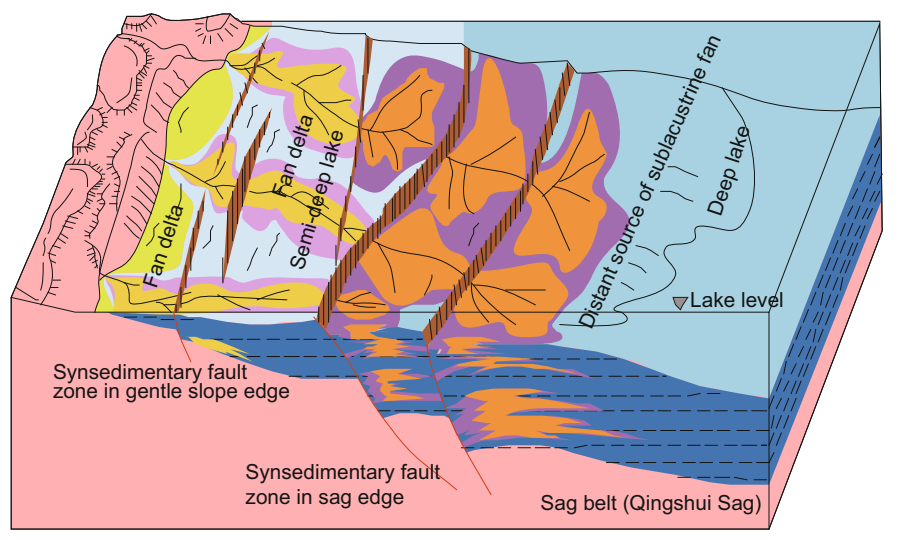

Fig. 8 Distribution model of the control of step-fault zones over the depositional system of Paleogene strata in the western slope of the WSLD

\subsubsection{Faulted scarp type slope break belt and nearshore subaqueous fans}

In general, the faulted scarp type slope break has high steep slope topography, which provides a sediment source and nearshore subaqueous deposition is dominant. It is characterized by dispersive river systems, small-scale deposition, and a narrow belt of depositional facies. The depression center and the depositional center were close to the scarp side, and the front of the fault scarp directly adjoined a deepwater lake area, which had the largest accommodation space in the lake basin.

In the Western Sag of the Liaohe Depression, the faulted scarp type slope breaks mainly developed in the eastern steep slope (Figs. 2, 5, 6). Sediments from the east of the sag directly accumulated in the deep water area at the foot of the scarp, leading to the formation of nearshore subaqueous fan depositional systems. The sand bodies of the nearshore subaqueous fans have far smaller distribution range than those of sublacustrine fans and mainly developed at the downthrown side of the fault. This type of depositional system of different sizes was mainly distributed along the boundary fault in the southeast depression and the Tai'an Sag. In the context of transgression, these depositional systems mostly showed retrograding stacking patterns.

\subsubsection{Steep slope type slope break belts and sublacustrine} fans

The formation of steep slope type break belts is associated 
with large basement faults as well, but the dip of the fault plane is slightly slower than that of a faulted scarp type break belt. The bottom topography adjacent to the fault is steep, or associated faults developed in the front. When the alluvial fan has migrated into the lake, fan deltas or nearshore subaqueous fans can be formed at the front of salients and may be retransported due to gravity. Sublacustrine fans or turbidite fans can develop in front of the low-lying areas.

In the WSLD, steep slope type slope breaks mainly developed in the eastern steep slope (Fig. 9). The boundary fault of the sag was steep, leading to a dramatic increase in the clastic depositional thickness on the downthrown side of the fault. A series of coarse clastic systems from the steep slopes was deposited and sublacustrine fans widely developed. Part of the clastic materials with high kinetic energy could be flushed into the central area of the sag, resulting in the formation of deep water fan deltas.

In summary, different types of syndepositional faults developed in various tectonic positions in multiple stages of the fault basin and further controlled the development and distribution of different types of depositional systems and sand bodies. The development of sand bodies was controlled by the fault terraces on steep slopes, the development of lowstand fan bodies was controlled by the fault terraces on gentle slopes, and the development of fluxoturbidite bodies was controlled by fault terraces or trough faults within the basin. The step-fault belts commonly resulted in belts of increased sand thickness and sand layer numbers, as well as the initial development position of the unconformity. These findings are of importance for locating stratigraphic unconformity hydrocarbon reservoirs.

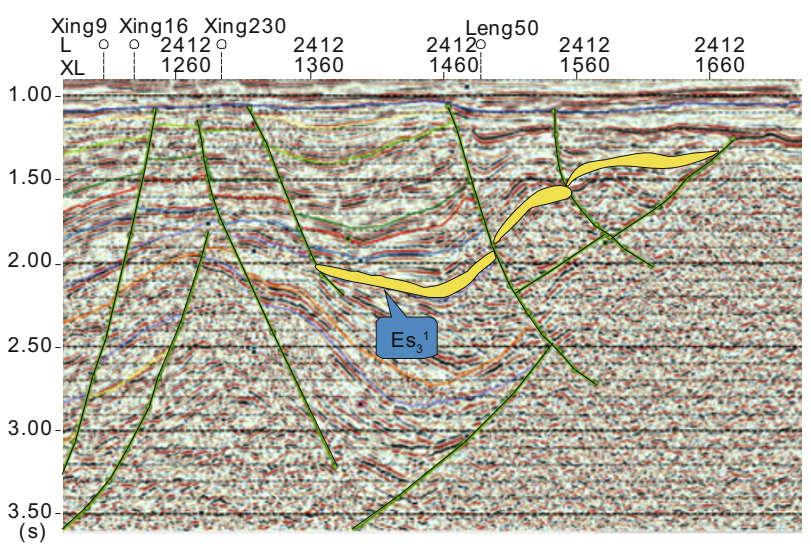

Fig. 9 Seismic reflection characteristics of the steep slope zone in the WSLD (after Bao et al, 2009)

\section{Conclusions}

Overall, the tectonic deformation of the Western Sag of the Cenozoic Liaohe Depression was characterized by superposition of faults and depression. Additionally, there existed relatively independent but correlated extensional tectonic systems $\left(\mathrm{E}_{2} \mathrm{~s}^{3}-\mathrm{E}_{2} \mathrm{~s}^{4}\right)$ and strike-slip tectonic systems $\left(E_{3} s^{1-2}-Q\right)$. The extensional tectonic system consisted of NNE-
NE-trending normal faults of different scales and controlled the formation and evolution of fault basins in the Paleogene Western Sag. These represent the most common evolutionary characteristics of the fault basins in eastern China.

In the continental fault basins, various tectonic styles coexisted in the Cenozoic sedimentation and followed certain distribution patterns. In the Paleogene, tectonic movements were dominated by block faulting. Multi-stage faulted slope-break zones were formed by different levels of syndepositional faults along steep or gentle slopes and subsags. These further controlled the style of paleotectonic frameworks and the tectonic palaeogeomorphological characteristics in the sag.

The Cenozoic tectonic evolution of the Western Sag generally involved two stages, i.e., rifting in the Paleogene and depression in the Neogene-Quaternary. The Paleogene rifting stage further involved four stages, i.e, an initial rifting stage, then an intense faulting stage, fault-depression transition stage, and finally a differential uplifting stage. Due to the changes in the structure, palaeo-landform, provenance, and climate, the pattern of deposition correspondingly changed during the different evolutionary stages in the Western Sag. Episodic faulting was an alternation of active and stationary tectonic phases, which respectively caused the expansion and shrinkage of the inner continental lacustrine basin. According to the tectonic development and evolutionary characteristics, the Paleogene depositional evolution of the WSLD can be divided into four stages with various depositional development characteristics.

The multi-stage tectonic evolution and episodic change in the subsidence rate commonly controlled the development of depositional system tracts and the distribution of depositional facies in fault basins, while different types of syndepositional faults developed in the evolutionary stages at different tectonic sites in the fault basins. These controlled the composition of the specific depositional facies tracts and the distribution of reservoir sand bodies. In addition, the development of sand bodies was controlled by the fault terraces on steep slopes, the development of low-stand fan bodies was controlled by the fault terraces in gentle slopes and the development of fluxoturbidite bodies was controlled by fault terraces or trough faults within the basin.

\section{Acknowledgements}

This study was financially supported by the National Basic Research Program of China (973 Program) (No. 2006CB202300) and the Major Scientific and Technical Project of China National Petroleum Corporation (No. 0701C-01-04).

\section{References}

Allen M B, Macdonald D I M, Zhao X, et al. Early Cenozoic two-phase extension and late Cenozoic thermal subsidence and inversion of the Bohai Basin, northern China. Marine and Petroleum Geology. 1997. 14(7-8): 951-972

Aschoff J L and Schmitt J G. Distinguishing syntectonic unconformity types to enhance analysis of growth strata: An example from the 
Cretaceous, Southeastern Nevada, U.S.A. Journal of Sedimentary Research. 2008. 78(9): 608-623

Bao Z D, Zhao L X, Wang Y, et al. The main control factors of sandbody reservoir development in rift-subsidence lake basin: An example from the Paleogene West Sag of Liaohe Basin. Geoscience. 2009. 23(4): 1-7 (in Chinese)

Barrier L, Nalpas T, Gapais D, et al. Influence of syntectonic sedimentation on thrust geometry. Field examples from the Iberian Chain (Spain) and analogue modeling. Sedimentary Geology. 2002. 146(1-2): 91-104

Bernal A and Hardy S. Syn-tectonic sedimentation associated with three-dimensional fault-bend fold structures: A numerical approach. Journal of Structural Geology. 2002. 24(4): 609-635

Carmona A, Clavera-Gispert R, Gratacos O, et al. Modelling syntectonic sedimentation: Combining a discrete element model of tectonic deformation and a process-based sedimentary model in 3D. Special Issue on Computational Methods for the Earth, Energy and Environment-IAMG 2009. Mathematical Geosciences. 2010. 42(5): 519-534

Contreras J and Scholz C H. Evolution of stratigraphic sequences in multisegmented continental rift basins: Comparison of computer models with the basins of the East African rift system. AAPG Bulletin. 2001. 85(9): 1565-1581

Cowie P A, Gupta S and Dawers N H. Implications of fault array evolution for synrift depocentre development: Insights from a numerical fault growth model. Basin Research. 2000. 12(3-4): 241261

Dawers N H and Underhill J R. The role of fault interaction and linkage in controlling synrift stratigraphic sequences: Late Jurassic, Statfjord east area, northern North Sea. AAPG Bulletin. 2000. 84(1): 45- 64

DeVault B and Jeremiah J. Tectonostratigraphy of the Nieuwerkerk Formation (Delfland subgroup), West Netherlands Basin. AAPG Bulletin. 2002. 86(10): 1679-1707

Duerto L and McClay K. The role of syntectonic sedimentation in the evolution of doubly vergent thrust wedges and foreland folds. Marine and Petroleum Geology. 2009. 26(7): 1051-1069

Feng Y L. Distribution of stratigraphic and lithologic reservoirs in sequence framework of rift-subsidence basin. Acta Petrolei Sinica. 2005. 26(4): 17-22 (in Chinese)

Fillon C, Huismans R S and van der Beek P. Syntectonic sedimentation effects on the growth of fold-and-thrust belts. Geology. 2012. 41(1): $83-86$

Fu X B. The structure-sedimentation model and reservoir forming of little half-graben basin: A case study of Guanzhen subsag in northern Jiangsu Basin. Geological Science and Technology Information. 2009. 28(2): 77-80 (in Chinese)

Gawthorpe R L and Leeder M R. Tectono-sedimentary evolution of active extensional basins. Basin Research. 2000. 12(3-4): 195-218

Gawthorpe R L, Fraser A J and Collier R E L. Sequence stratigraphy in active extensional basins: Implications for the interpretation of ancient basin-fills. Marine and Petroleum Geology. 1994. 11(6): 642-658

Gomez E, Jordan T E, Allmendinger R, et al. Syntectonic Cenozoic sedimentation in the northern middle Magdalena Valley Basin of Colombia and implications for exhumation of the Northern Andes. Geological Society of America Bulletin. 2005. 117(5): 547-569

Hoppie B and Garrison R E. The Cuyama Strike-Slip Basin, California, U.S.A: An exemplar of contrasting syntectonic and post-tectonic strata. Journal of Sedimentary Research. 2002. 72(2): 268-287

Jones M A, Heller P L, Roca E, et al. Time lag of syntectonic sedimentation across an alluvial basin: Theory and example from the Ebro Basin, Spain. Basin Research. 2004. 16(4): 467-488

Liesa C L, Soria A R, Meléndez N, et al. Extensional fault control on the sedimentation patterns in a continental rift basin: El Castellar Formation, Galve sub-basin, Spain. Journal of the Geological Society. 2006. 163(3): 487-498

Lin C S, Zheng H R, Ren J Y, et al. The control of syndepositional faulting on Paleogene depositional filling in Dongying and Zhanhua sags, Bohai Bay Basin. Science in China (Series D). 2003. 33(11): 1025-1036 (in Chinese)

Li P L, Hou H B and Ma H F. Tectonics and petroleum potential of the East China Sea shelf rift basin. Acta Geologica Sinica (English Edition). 2000. 74(3): 651-660

Liu G Z, Bao Z D and Wang Y M. Characteristics of valley-slope break zone in the western slope of Songliao Basin and its control over reservoir distribution. Journal of China University of Petroleum (Edition of Natural Science). 2008. 32(6): 18-22 (in Chinese)

Liu X F and Zhang C M. Nanpu Sag of the Bohai Bay Basin: A transtensional fault-termination basin. Journal of Earth Science. 2011. 22(6): 755-767

McLeod A E, Underhill J R, Davies S J, et al. The influence of fault array evolution on synrift sedimentation patterns: Controls on deposition in the Strathspey-Brent-Statfjord half graben, northern North Sea. AAPG Bulletin. 2002. 86(6): 1061-1093

Morley C K. Patterns of displacement along large normal faults: Implications for basin evolution and fault propagation, based on examples from East Africa. AAPG Bulletin. 1999. 83(4): 613-634

Morley C K. Evolution of large normal faults: Evidence from seismic reflection data. AAPG Bulletin. 2002. 86(6): 961-978

Morley C K and Wonganan N. Normal fault displacement characteristics, with particular reference to synthetic transfer zones, Mae Moh mine, northern Thailand. Basin Research. 2000. 12(3-4): 307-327

Pascucci V, Costantini A, Martini I P, et al. Tectono-sedimentary analysis of a complex, extensional, Neogene basin formed on thrust-faulted, Northern Apennines hinterland, Radicofani Basin, Italy. Sedimentary Geology. 2006. 183(1-2): 71-97

Roberts G P and Michetti A M. Spatial and temporal variations in growth rates along active normal fault systems: An example from the LazioAbruzzo Apennines, central Italy. Journal of Structural Geology. 2004. 26(2): 339- 376

Schlische R W. Half-graben filling models: Implications for the evolution of continental extensional basins. Basin Research. 1991. 3: 123-141

Song G Q. Fault-depression transformation system and "T-S" control reservoir mode of stratigraphic overlap pool—an example from Jiyang Depression. Acta Geologica Sinica. 2007. 81(9): 1208-1214 (in Chinese)

Tang L J and Cui M. Structural deformation and fluid flow from East Sichuan to the northwestern periphery of the Xuefeng Uplift, China. Petroleum Science. 2012. 9(4): 429-435

Tong H M. Sandbox modeling of fault formation and evolution in the Weixinan Sag, Beibuwan Basin, China. Petroleum Science. 2012. 9(2): 121-128

Tong H M, Mi R S, Yu T C, et al. The strike-slip tectonics in the Western Liaohe Depression, Bohai Bay Basin. Acta Geologica Sinica. 2008. 82(8): 1017-1026 (in Chinese)

Tong H M, Yu F S and Geng C B. Characteristics and evolution of 
strike-slip tectonics of the Liaohe Western Sag, Bohai Bay Basin. Petroleum Science. 2008. 5(3): 223-229

Walsh J J, Bailey W R, Childs C, et al. Formation of segmented normal faults: A 3-D perspective. Journal of Structural Geology. 2003. 25(8): 1251- 1262

Xu G S, Ma R L, Gong D Y, et al. Features of the fault system and its relationship with migration and accumulation of hydrocarbon in Liaodong Bay. Petroleum Science. 2011. 8(3): 251-263

Yang Y T, Li W and Ma L. Tectonic and stratigraphic controls of hydrocarbon systems in the Ordos Basin: A multicycle cratonic basin in central China. AAPG Bulletin: Methods in Exploration Series. 2005. 89(2): 255-269

Yin Z J, Peng S M, Li Y X, et al. Geological model of Member 3 of Shahejie Formation reservoir in Liuzan Oilfield, eastern Hebei Province. Petroleum Science. 2006. 3(2): 28-33

Young M J, Gawthorpe R L and Sharp I R. Normal fault growth and early syn-rift sedimentology and sequence stratigraphy: Thal Fault, Suez Rift, Egypt. Basin Research. 2003. 15(4): 479-502
Zhang C H, Wu G G, Wang G H, et al. Northwest trending tectonic belt in the middle Yanshan Orogenic Belt of northeast Hebei Province, North China: Tectonic evolution and geochronology. Science in China Series D: Earth Sciences. 2004. 47(10): 896-911

Zheng H R and He Z Q. Lithologic hydrocarbon deposits in rift lake basins in eastern China. Acta Geologica Sinica (English Edition). 2004. 78(3): 644-650

Zhong D K, Zhu X M and Zhang Q. The Sedimentary system and evolution of the Early Tertiary in the Sunda Basin, Indonesia. Petroleum Science. 2006. 3(1): 1-11

Zhu H T, Du Y S, Liu K Y, et al. Sequence stratigraphic delineation and correlation of the Dongying Formation in the Nearshore and Adjacent Sea Areas, Bohai Bay Basin. Journal of China University of Geosciences. 2008. 19(1): 54-64

Zhuravlev V A and Shipilov E V. Structure of the basins of the White Sea rift systems. Oceanology. 2008. 48(1): 114-122

(Edited by Hao Jie) 